\title{
Karakteristik Morfologi dan Morfometrik Lebah Madu Tak Bersengat (Apidae; Melliponinae) pada Koloni di Daerah Pesisir Pulau Ambon
}

\author{
Morphological and Morphometric Characteristics of Stingless Bee (Apidae; Melliponinae) in the \\ Colonies on Coastal Areas of Ambon Island
}

\section{Jacobus S.A. Lamerkabel ${ }^{1}$, Victor G. Siahaya ${ }^{1, *}$, Wulandari Saepuloh ${ }^{2}$, Anang Lastriyanto ${ }^{3}$, Mochammad Junus $^{4}$, Erwan ${ }^{5}$, Jati Batoro ${ }^{6}$, Firman Jaya ${ }^{7}$, Dewi Masyithoh ${ }^{8}$}

${ }^{1}$ Jurusan Budidaya Pertanian, Fakultas Pertanian, Universitas Pattimura, Jl. Ir. M. Putuhena, Kampus Poka, Ambon 97233, Indonesia

${ }^{2}$ Program Studi Agroteknologi, Fakultas Pertanian, Universitas Pattimura, Jl. Ir. M. Putuhena, Kampus Poka, Ambon 97233, Indonesia

${ }^{3}$ Jurusan Keteknikan Pertanian, Fakultas Teknologi Pertanian, Universitas Brawijaya, Jl. Veteran Malang 65145, Indonesia

${ }^{4}$ Minat Produksi Ternak, Fakultas Peternakan, Universitas Brawijaya, Jl. Veteran Malang 65145, Indonesia ${ }^{5}$ Program Studi Peternakan, Fakultas Peternakan, Universitas Mataram, Jl. Majapahit No 62, Mataram 83125, Indonesia ${ }^{6}$ Jurusan Biologi, Fakultas Matematika dan Ilmu Pengetahuan Alam, Universitas Brawijaya, Jl. Veteran Malang 65145

${ }^{7}$ Minat Teknologi Hasil Ternak, Fakultas Peternakan, Universitas Brawijaya, Jl. Veteran Malang 65145, Indonesia ${ }^{8}$ Jurusan Peternakan, Fakultas Peternakan, Universitas Islam Malang (dan P.T. Kembang Joyo Sriwijaya), Jalan Mayjen Haryono No 193, Malang 65144, Indonesia

*Email Penulis Korespondensi: vg.siahaya@ faperta.unpatti.ac.id

\begin{abstract}
This study aimed to describe the morphological characters and morphometric measurements of worker level from the genus and species of stingless bee colonies in coastal areas. Observation of morphological characters and morphometric measurements used a microscope (stereo model Nikon C-LEEDS equipped with obtilab viewers software camera and image raster). The stingless bee species found in coastal areas belonged to the genus Tetragonula which consisted of Tetragonula sapiens and T. clypearis. T. sapiens was found in two locations, namely the coast of Airlow Hamlet and Negeri Rutong. T. clypearis was found in four locations, i.e., on the coast of Dusun Airlow, Negeri Rutong, Negeri Hukurila and Dusun Seri. Morphological identification was done by identifying ten morphological characters, and morphometric identification was done by measuring fourteen body parts. The results of this study indicated that the morphological and morphometric characters of T. sapiens workers were dominantly black in color with a body size of 3.74-4.25 mm. The first through the sixth abdomen tergites were black. The morphological and morphometric characters T. clypearis had a brownish black body color with a body size of 2.81-3.38 mm, a black thorax covered by six longitudinal hair bands and each separated by five conspicuous glabrous, the first and second abdomen tergites were brownish whereas the third through the sixth were black.
\end{abstract}

Key words: Ambon Island, morphology; morphometric; stingless bees

\section{ABSTRAK}

Penelitian ini bertujuan untuk mendeskripsikan karakter morfologi dan pengukuran morfometrik strata pekerja dari genus dan spesies lebah tak bersengat koloni daerah pesisir. Pengamatan karakter morfologi dan pengukuran morfometrik menggunakan mikroskop (stereo model Nikon C-LEEDS yang dilengkapi kamera software obtilab viewers dan image raster). Spesies lebah tak bersengat yang ditemukan di daerah pesisir pantai tergolong dalam genus Tetragonula yang terdiri dari Tetragonula sapiens dan T. clypearis. T. sapiens ditemukan di dua lokasi yaitu pesisir pantai Dusun Airlow dan Negeri Rutong. T. clypearis ditemukan di empat lokasi, yaitu di pesisir pantai Dusun Airlow, Negeri Rutong, Negeri Hukurila dan Dusun Seri. Identifikasi morfologi dilakukan dengan mengidentifikasi sepuluh karakter morfologi dan identifikasi morfometrik dilakukan dengan cara mengukur empat belas bagian tubuh. Hasil penelitian ini menunjukan karakter morfologi dan morfometrik tubuh pekerja T. sapiens dominan berwarna hitam dengan ukuran tubuh 3.74-4.25 mm. Abdomen dan tergite satu sampai enam berwarna hitam. Karakter morfologi dan morfometrik T. clypearis memiliki warna tubuh hitam kecoklatan dengan ukuran tubuh 2.81-3.38 mm, thorax berwarna hitam yang ditutupi oleh enam hair bands longitudinal dan masing-masing dipisahkan oleh lima glabrous yang mencolok, abdomen dan tergite pertama sampai kedua berwarna kecoklatan sedangkan tergite ketiga sampai enam berwarna hitam.

Kata kunci: lebah tak bersengat, morfologi, morfometrik, Pulau Ambon 


\section{PENDAHULUAN}

Hasil penelitian para ahli arkeologi menunjukkan bahwa lebah madu sudah ada di dunia sejak zaman tersier, sekitar 56 juta tahun yang lalu. Sejak zaman purba manusia berburu sarang lebah madu yang terdapat di celah-celah tebing batu dan rongga-rongga cabang atau batang pohon untuk diambil madunya. Madu yang dihasilkan oleh lebah merupakan anugerah alam yang menakjubkan karena khasiat yang dimilikinya (Sihombing, 2005).

Indonesia dikenal di dunia internasional sebagai negara yang kaya akan jenis-jenis lebah madu, karena memiliki keanekaragaman jenis lebah madu bersengat dan lebah madu tak bersengat (Suranto, 2004). Lebah tak bersengat sub famili Melliponinae adalah salah satu lebah yang sangat morfologis dengan perilaku yang berbeda-beda, serta memiliki beragam spesies di antara lebah corbiculate (Apini, Bombini dan Meliponini) (Michener, 2007; Rasmussen dan Cameron; 2010).

Lebah madu tak bersengat mempunyai peranan penting selain sebagai penyerbuk potensial untuk peningkatan produksi berbagai tanaman, juga sebagai penghasil madu, propolis (perekat), roti lebah (bee bread), dan lilin lebah (bee wax) yang memiliki nilai ekonomi tinggi dan berkhasiat bagi kesehatan (Laurino et al., 2006; Leonhardt et al., 2007; Michener, 2007; Kumar et al., 2012; Lamerkabel, 2017).

Di Maluku sudah ada laporan tentang jenis lebah tak bersengat dari genus Tetragonula yang ditemukan di Pulau Ambon, yaitu Tetragonula fuscobalteata (C.) dan Tetragonula biroi (F.) pada area pemukiman dan hutan di Negeri Hatu, Hila, Airlow, Latuhalat dan Dusun Seri. Koloni Tetragonula fuscobalteata (C.) terbanyak terdapat di area pemukiman yang bersarang pada celah-celah batu pondasi, celah-celah batu dinding rumah, rongga bingkai pintu atau jendela, rongga bingkai kerangka jendela nako, bambu penyangga atap atau tiang rumah dan dalam pipa besi jembatan (Lamerkabel, 2017; Lamerkabel et al., 2018).

Koloni Tetragonula biroi (F.) ditemukan terbanyak di areal hutan, tempat persarangannya adalah pada rongga batang pohon hidup atau sudah lapuk, dan celah-celah tebing batu (Lamerkabel, 2017; Lamerkabel et al., 2018). Tempat bersarang, arsitektur sarang, perilaku dan karakter morfologi, morfometrik, sebaran dan produk-produk dari jenis-jenis lebah madu tak bersengat perlu diteliti untuk mendapatkan data ilmiah dalam upaya konservasi, pengembangan teknologi budidaya dan pengolahan produk-produknya. Penelitian identifikasi lebah madu tak bersengat melalui pengamatan karakter morfologi dan pengukuran morfometrik strata pekerja, untuk mengetahui genus dan spesies khususnya koloni di habitat pesisir pantai pada beberapa Pulau besar dan Pulau kecil di Maluku relatif sedikit. Oleh karena itu, perlu dilakukan sebuah penelitian tentang karakter morfologi dan morfometrik lebah madu tak bersengat pada koloni di daerah pesisir Pulau Ambon.

\section{BAHAN DAN METODE}

\section{Waktu dan Tempat}

Penelitian dilaksanakan di empat tempat berbeda di Pulau Ambon, yaitu di area pemukiman penduduk daerah pesisir pantai (Negeri Airlow, Hukurila, Seri dan Rutong). Pencarian sarang koloni untuk mengambil dan mengoleksi strata pekerja di masing-masing tempat dilaksanakan pada bulan Oktober 2019. Identifikasi pengamatan karakter morfologi dan pengukuran morfometrik strata pekerja dilakukan di Laboratorium Zoologi LIPI, Cibinong, Bogor, pada bulan November sampai Desember 2019.

\section{Bahan dan Alat}

Bahan yang digunakan dalam penelitian ini adalah lebah dari strata pekerja, kertas tisu dan alkohol $70 \%$.

Alat-alat yang digunakan dalam penelitian ini adalah topi, masker, sarung tangan, tisu, kertas label, plastik bening, pinset, tabung koleksi sampel strata pekerja, kamera, selotip, penggaris besi, micropint, gunting, jarum pentul, pinset, lampu belajar, gabus, cawan petri, oven, kulkas, laptop, alat tulis-menulis dan mikroskop stereo model Nikon CLEEDS yang dilengkapi kamera dengan software Obtilab.

Metode yang digunakan dalam penelitian ini adalah metode deskriptif, yakni mengidentifikasi lebah madu tak bersengat melalui pengamatan karakter morfologi dan pengukuran morfometrik strata pekerja dari masing-masing sarang koloni di daerah pesisir.

\section{Pencarian Sarang Koloni}

Pencarian sarang koloni lebah madu tak bersengat menggunakan metode jelajah (Bookhout, 1996), sedangkan pengambilan strata pekerja mengikuti cara penangkapan (Lamerkabel, 2017). Penjelajahan dilakukan dengan berjalan kaki ke area pemukiman penduduk di pesisir pantai untuk mencari dan menemukan tempat persarangan koloni lebah tak bersengat sesuai lokasi yang ditentukan. 


\section{Pengambilan Sampel}

berikut:

Cara pengambilan sampel strata pekerja mengikuti metode yang dikembangkan oleh Lamerkabel (2017) sebagai

(1) mepasangkan kantong plastik bening (panjang $37 \mathrm{~cm}$; lebar $25 \mathrm{~cm}$; dan diameter $25 \mathrm{~cm}$ ) yang diberi selang pada bagian ujungnya kecorong pintu masuk (entrance) sarang lebah madu tak bersengat;

(2) mengeketuk tempat persarangan menggunakan palu yang terbuat dari kayu sebanyak kurang lebih 30-40 kali sehingga strata pekerja akan keluar dan terperangkap pada kantong plastik;

(3) mengangkat kantong plastik yang terisi individu-individu strata pekerja (100 individu) dari pintu sarang, kemudian memasukkan kertas tisu yang sudah diberi alkohol $70 \%$ untuk mematikan individu-individu tersebut;

(4) memasukkan individu-individu yang sudah mati ke dalam tube berisi alkohol 70\%;

(5) menutup bagian penutup tube rapat-rapat kemudian membalut dengan selotip;

(6) pada bagian dinding tube dipasang label bertulisan nomor koloni, lokasi, tempat persarangan, dan tanggal pengambilan;

(7) mengulangi cara penangkapan individu strata pekerja pada semua sarang koloni yang ditemukan di setiap lokasi;

(8) mengkoleksi tabung (tube) sampel-sampel yang berisi individu-individu strata pekerja dan yang sudah diberi label, sebagai spesimen.

Jumlah sarang (koloni) dan jumlah individu strata pekerja pada empat tempat (Negeri Halong, Dusun Airlow, Dusun Seri dan Negeri Rutong) di Pulau Ambon berjumlah 15 koloni dengan masing-masing diambil sebanyak 50 individu. Total individu strata pekerja dari semua tempat adalah sebanyak 3000 individu.

\section{Koleksi Spesimen}

Koleksi specimen bertujuan untuk mendapatkan lebah yang akan dijadikan sampel dari empat tempat berbeda dengan jumlah individu yang diambil masing-masing sebanyak 50 koloni pekerja per tempat.

\section{Identifikasi Spesimen Strata Pekerja}

Spesimen-spesimen individu strata pekerja lebah tak bersengat diindentifikasi berdasarkan karakter morfologi dan morfometrik, kemudian diverifikasi menggunakan spesimen yang ada pada Museum Zoologicum Bogoriense (MZB), Bidang Zoologi, Pusat Penelitian Biologi, Lembaga Ilmu Pengetahuan Indonesia (LIPI) Cibinong, Bogor.

Identifikasi lebah madu tak bersengat berdasarkan karakter morfologi dan morfometrik, mengikuti Sakagami (1978); Sakagami dan Inoue (1987); Sakagami et al. (1990); Dollin et al. (1997); dan Smith (2012). Pengamatan karakter morfologi dan pengukuran morfometrik menggunakan mikroskop stereo model Nikon C-LEEDS, yang dilengkapi kamera dengan software Obtilab viewer dan image raster. Identifikasi morfologi dilakukan dengan mengidentifikasi sepuluh karakter morfologi berdasarkan Sakagami (1978), yaitu: warna tubuh, thorax, mesoscutum, mesoscutellum, propodeum, abdomen, warna sayap depan, jumlah hammuli, rambut-rambut posteriorhind tibia, dan elliptical disc pada bagian dalam hind basitarsus. Sedangkan morfometrik strata pekerja yang diukur adalah : panjang tubuh (PT), panjang kepala (PK), lebar mata (LM), lebar gena (LG), panjang malar (PML), lebar flagellomere II (LF), panjang sayap dan tegula (WL1), panjang sayap (PS), panjang jarak antara venasi $M-C u$ dan basal marginal cell, panjang dan lebar tibia belakang (PTB dan LTB), lebar dan panjang basitarsus (LBB dan PBB) (Sakagami, 1978).

\section{Analisis Data}

Data hasil pengamatan karakter morfologi dan pengukuran morfometrik strata pekerja lebah madu tak bersengat masing-masing koloni dideskripsikan dan ditampilkan dalam bentuk tabel, gambar dan grafik.

\section{HASIL DAN PEMBAHASAN}

\section{Karakter Morfologi}

Identifikasi morfologi dua spesies lebah tak bersengat yang ditemukan dari hasil penelitian pada empat tempat di Pulau Ambon yaitu desa Airlow. Hukurila, Seri dan Rutong, tergolong dalam genus Tetragonula, yang terdiri dari Tetragonula sapiens dan Tetragonula clypearis. Adapun karakter morfologi dari genus Tetragonula yaitu mempunyai dua gigi kecil, ruang malar lebih pendek dari lebar segmen antena, daerah propodeum pada bagian tengah tidak berambut dan mengkilap, terdapat lima hammuli di sayap belakang, dan pinggir tungkai belakang terdapat rambut pendek serta sebagian besar plumose. 

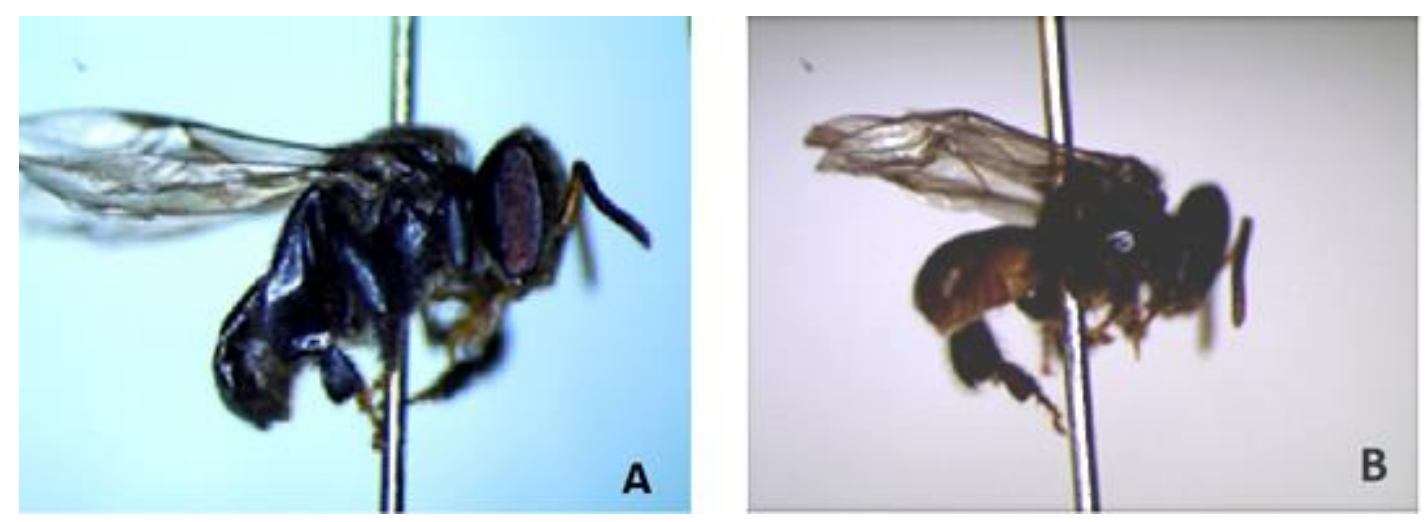

Gambar 1. Spesies lebah tak bersengat asal Pulau Ambon: (A) Tetragonula sapiens dan (B) Tetragonula clypearis

Tubuh pekerja $T$. sapiens dominan berwarna hitam dengan ukuran tubuh 3.74-4.25 mm, mesoscutum ditutupi oleh rambut-rambut berwarna kecoklatan, mesoscutellum menonjol menutupi propodeum, propodeum bagian tengah tidak berambut, abdomen tergite satu sampai enam berwarna hitam, warna sayap transparan dan terdapat lima hammuli di bagian sayap belakang, rambut pada posterior hind tibia bercabang dan terdapat elliptical disc pada hind basitarsus.

Tubuh pekerja $T$. clypearis memiliki warna hitam kecoklatan dengan ukuran 2.81-3.38 mm, thorax berwarna hitam yang ditutupi oleh enam hair bands longitudinal dan masing-masing dipisahkan oleh lima glabrous yang mecolok, mesoscutellum menonjol menutupi propodeum, propodeum bagian tengah tidak berambut, abdomen dari tergite pertama sampai kedua berwarna kecoklatan sedangkan tergite tiga sampai enam berwarna hitam, warna sayap transparan dan terdapat lima hammuli di bagian sayap belakang, rambut pada posterior hind tibia bercabang dan terdapat eliptical disc pada hind basitarsus.

Tabel 1. Karakteristik morfologi dari dua spesies lebah tak bersengat asal Pulau Ambon berdasarkan kunci identifikasi Indo-Malayan stingless bee (Sakagami et al., 1990; Rasmussen, 2008; Smith, 2012) dan Australian stingless bee (Dollin et al., 1997)

\begin{tabular}{|c|c|c|c|}
\hline \multirow{2}{*}{ No. } & \multirow{2}{*}{ Karakter } & \multicolumn{2}{|c|}{ Spesies } \\
\hline & & T. clypearis & T. sapiens \\
\hline 1. & Warna tubuh & Hitam kecoklatan & Hitam \\
\hline 2. & Thorax & Hitam & Hitam \\
\hline 3. & Mesoscutum & $\begin{array}{l}\text { Terdapat } 6 \text { hair bands (G1, G2, G3 } \\
\text { jelas) }\end{array}$ & $\begin{array}{l}\text { G1 lebih sempit, G2 tidak jelas, G3 } \\
\text { tidak ada }\end{array}$ \\
\hline 4. & Mesoscutellum & Menonjol menutupi propodeum & Menonjol menutupi propodeum \\
\hline 5. & Propodeum & Tidak berambut pada bagian tengah & Tidak berambut pada bagian tengah \\
\hline 6. & Abdomen & Hitam kecoklatan & Hitam \\
\hline 7. & Warna sayap depan & Transparan & Transparan \\
\hline 8. & Hammuli & 5 & 5 \\
\hline 9. & $\begin{array}{l}\text { Rambut pada posterior } \\
\text { hind tibia }\end{array}$ & Bercabang & Bercabang \\
\hline 10. & $\begin{array}{l}\text { Eliptical disc pada hind } \\
\text { basitarsus }\end{array}$ & Ada & Ada \\
\hline
\end{tabular}

\section{Karakteristik Morfometrik}

Pengukuran morfometrik dilakukan dengan mengukur empat belas bagian tubuh, meliputi: panjang tubuh (PT), panjang kepala (PK), lebar mata (LM), lebar gena (LG), panjang malar space (PM), lebar flagellomere ke II (LF), panjang sayap dan tegula (WL1), panjang sayap (PS) panjang jarak antara venasi M-Cu, panjang dan lebar hind tibia (PHB dan LHB), lebar dan panjang hind basitarsus (LHB dan PHB) (Sakagami, 1978).

Morfometrik lebah pekerja T. sapiens memiliki panjang tubuh 3.74-4.25 mm, lebar mata 0.37-0.52 mm, panjang sayap depan dari tegula 4.29-4.67 mm, panjang malar space lebih pendek dari lebar flagellomere antena ke II (0.02$0.03 \mathrm{~mm}$ dan 0.13-0.16 mm), panjang jarak venasi M-Cu 0.98-1.25 mm, panjang hind tibia 1.54-1.84 mm, lebar hind tibia 0.5-0.64 mm, panjang hind basitarsus 0.47-0.72 mm dan lebar hind basitarsus 0.26-0.38 (Tabel 2). 
Tabel 2. Morfometrik lebah pekerja Tetragonula sapiens

\begin{tabular}{rcc}
\hline No. & Karakter & Rata-rata \\
\cline { 2 - 3 } 1. & Lebar kepala & $1.77-1.81$ \\
2. & Panjang kepala & $1.47-1.55$ \\
3. & Lebar mata & $0.37-0.52$ \\
4. & Lebar gena & $0.27-0.47$ \\
5. & Malar space & $0.02-0.03$ \\
6. & Lebar flagellomere ke-II & $0.13-0.16$ \\
7. & Panjang tubuh & $3.74-4.25$ \\
8. & Panjang sayap termasuk tegula & $4.29-4.67$ \\
9. & Panjang sayap & $3.81-4.25$ \\
10. & Panjang antara M-Cu dan Basal marginal cell & $0.98-1.25$ \\
11. & Panjang hind tibia & $1.54-1.84$ \\
12. & Lebar hind tibia & $0.5-0.64$ \\
13. & Panjang hind basitarsus & $0.47-0.72$ \\
14. & Lebar hind basitarsus & $0.26-0.38$ \\
\hline
\end{tabular}

\section{Principal Component Analysis (PCA)}

Hasil analisis PCA menunjukkan nilai total PC1 dan PC2 sebesar 79.4\% dengan nilai PC1 71\% dan PC2 $8.4 \%$. Sesuai dengan identifikasi morfologi, karakter ukuran panjang sayap dan lebar gena memiliki nilai tertinggi pada PC1 dan PC2, yaitu 0.309 dan 0.449. Nilai karakter yang dihasilkan pada PC1 dan PC2 digunakan untuk menentukan karakter yang paling berpengaruh dalam pemisahan spesies. Nilai PC1 dan PC2 kemudian diplotkan untuk visualisasi hasil analisis. Hasil visualisasi pada plot PCA (Gambar 2) menunjukkan dua spesies Tetragonula terpisah dengan $T$. clypearis terletak di kuadran satu dan dua, sedangkan $T$. sapiens tersebar di kuadran satu, dua dan tiga. Hal tersebut juga terjadi pada data sekunder yaitu $W$. incisa terletak di kuadran sepuluh.

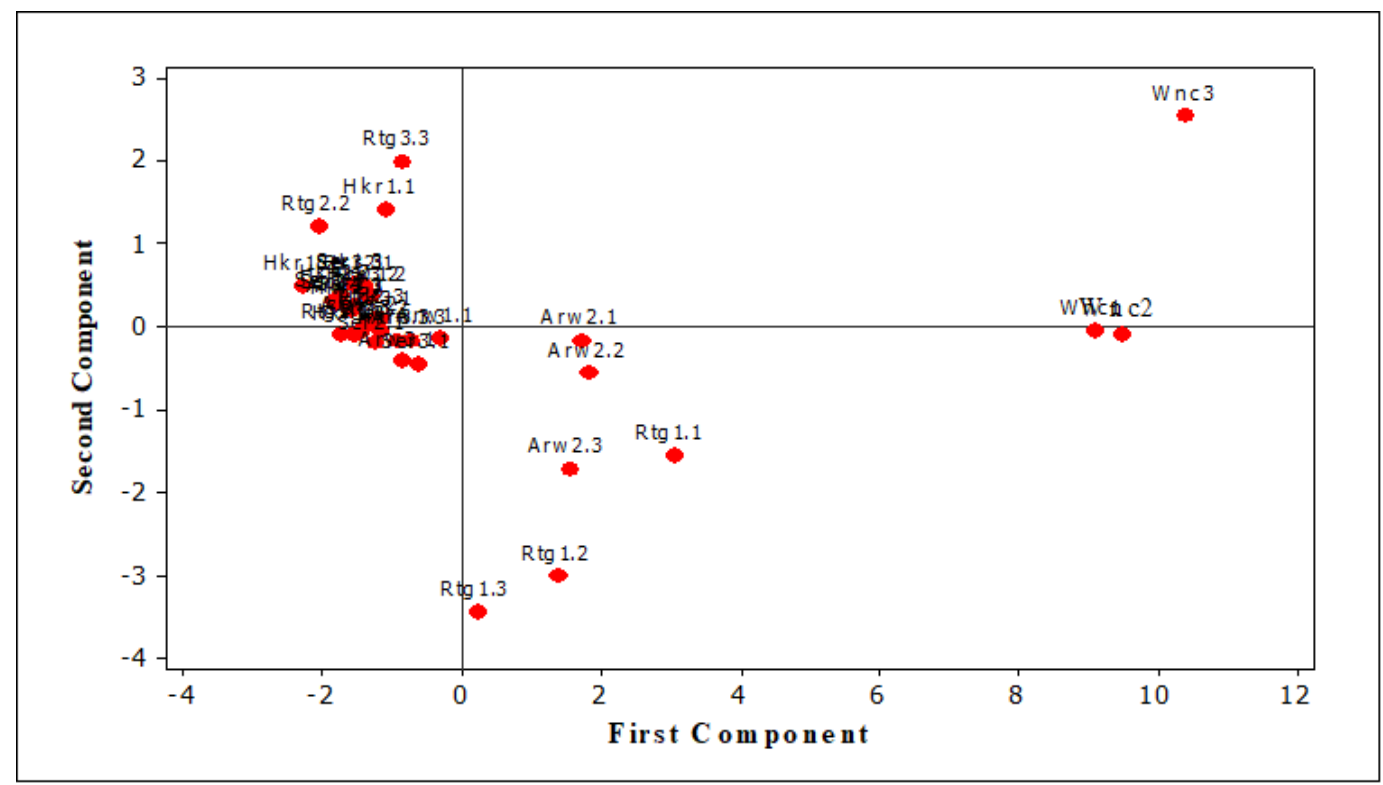

Gambar 2. Principal Component Analysis berdasarkan pengukuran empat belas karakter morfometrik menunjukkan pemisahan pada masing-masing spesies lebah tak bersengat 
(A)

Tetragonula clypearis

(B)

(C)

(D)

(E)

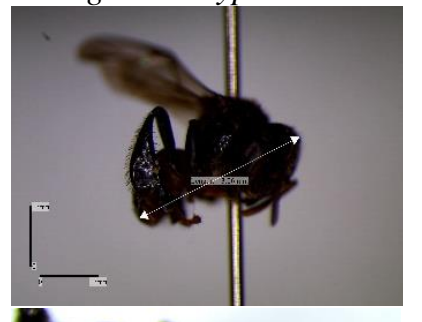

(F)

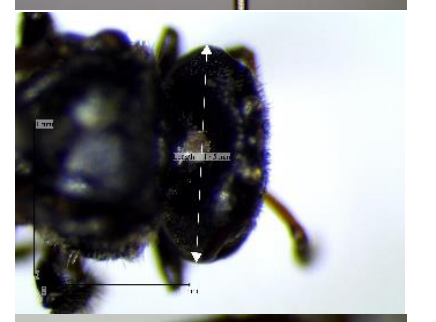

Tetragonula sapiens

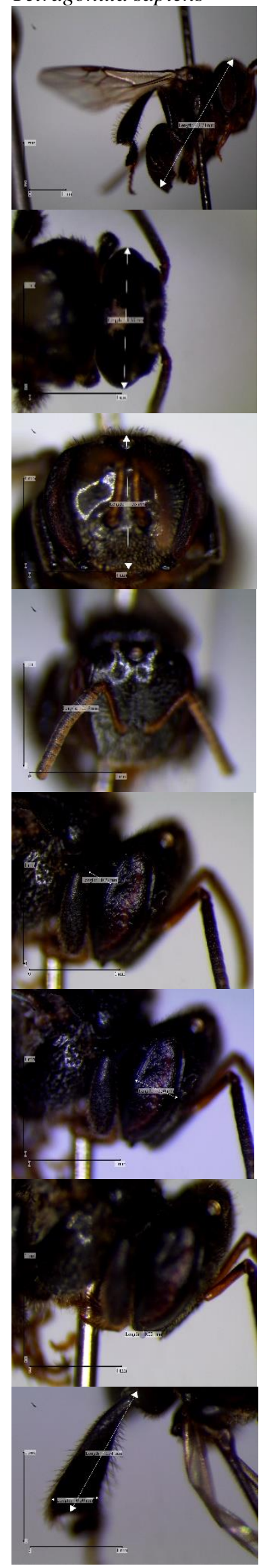


(I)

(J)

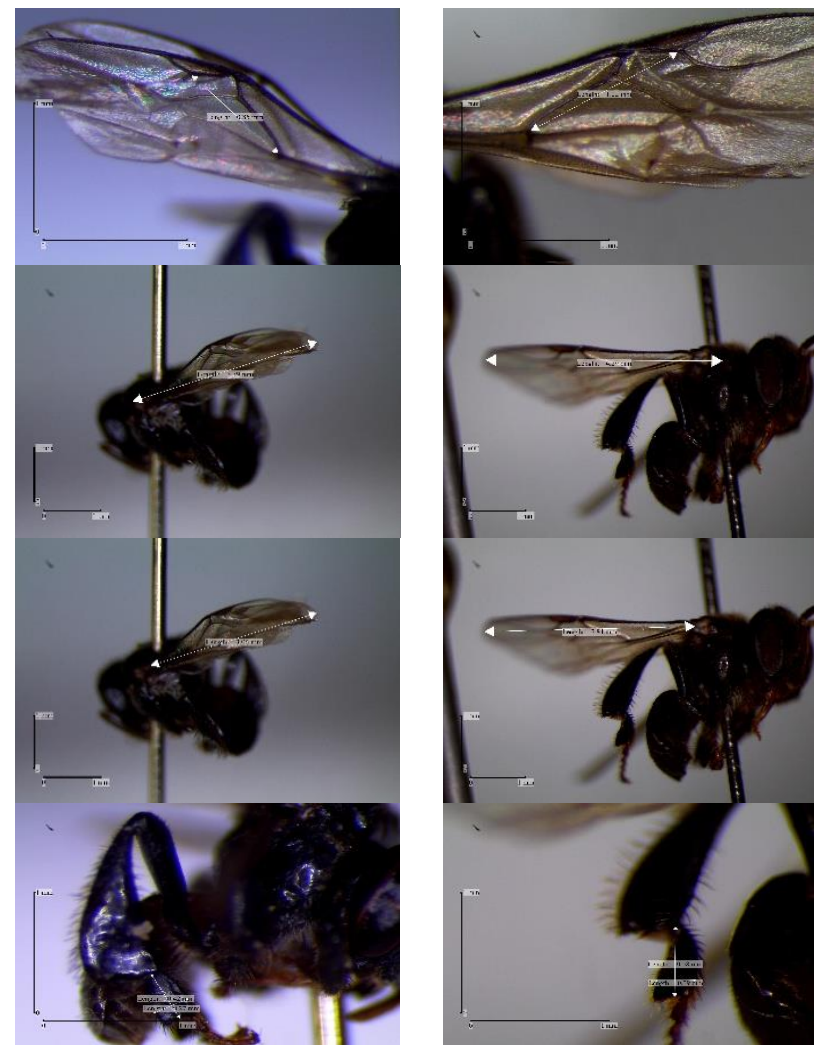

Gambar 3. Empat belas karakter morfologi stingless bee yang diukur untuk analisis morfometrik menggunakan PCA: (A) panjang tubuh, (B) lebar kepala, (C) panjang kepala, (D) lebar flagellomere kedua, (E) lebar gena, (F) lebar mata, (G) malar space, (H) lebar dan panjang hind tibia, (I) jarak antara venasi M-Cu basal marginal cell, (J) panjang sayap dan tegula, (K) panjang sayap, dan (L) lebar dan panjang hind basitarsus

\section{Pembahasan}

Pemukiman yang terdapat di pesisir pantai pada umumnya berbahan kayu dan bebatuan sehingga memungkinkan lebah tak bersengat yang hidup liar dapat membuat sarang. Selain itu, ketersediaan sumber pakan pun mempengaruhi kelangsungan hidup dan daya tarik lebah untuk membuat sarang.

Dua spesies lebah tak bersengat yang ditemukan pada penelitian ini tergolong dalam genus Tetragonula, yaitu Tetragonula sapiens yang merupakan spesies lebah tak bersengat asal Australasia dan Tetragonula clypearis yang merupakan lebah tak bersengat asal Wallacea, New Guinea dan Australia Utara. Tetragonula sapiens ditemukan hanya di dua lokasi, yaitu Dusun Airlow dan Negeri Rutong, sedangkan Tetragonula clypearis ditemukan di empat lokasi, yaitu Negeri Hukurila, Dusun Seri, Negeri Rutong dan Dusun Airlow.

Karakter morfologi lebah pekerja T. sapiens yang ditemukan sesuai dengan deskripsi Dollin et al. (1997). Panjang tubuh $(3.74-4.25 \mathrm{~mm})$ dan panjang sayap termasuk tegula $(4.29-4.67 \mathrm{~mm})$ dari lebah pekerja Tetragonula sapiens yang ditemukan tidak terlalu berbeda dengan spesimen yang dilaporkan oleh Dollin et al. (1997) yang memiliki ukuran panjang tubuh 3.6-4.2 mm dan sayap termasuk tegula 4.2-4.5 mm.

Hasil penelelitian, lebah Tetragonula sapiens hanya ditemukan di dua lokasi, masing-masing memiliki karakter morfologi yang berbeda. Ukuran tubuh lebah pekerja T. sapiens di Negeri Rutong lebih panjang dibandingkan dari Dusun Airlow, sedangkan panjang sayap di Dusun Airlow lebih panjang dibandingkan di Negeri Rutong.

Karakter morfologi lebah pekerja Tetragonula clypearis hampir mirip dengan morfologi Tetragonula fuscobalteata yang memiliki karakter khusus, yaitu terdapat 6 hair bands di mesoscutum. Faktor pembeda di antara keduanya seperti yang telah dideskripsikan oleh Dollin et al. (1997) panjang sayap termasuk tegula lebah pekerja $T$. clypearis (3.4-3.7 mm) lebih panjang dibandingkan T. fuscobalteata (3.3-3.4 mm). Dalam penelitian ini panjang sayap termasuk tegula lebah pekerja T. clypearis $(3.23-3.68 \mathrm{~mm}$ ) tidak berbeda jauh dengan yang dideskripsikan oleh Dollin et al. (1997).

Dari penelitian ini didapatkan bahwa lebah pekerja T. clypearis yang ditemukan di empat lokasi yang berbeda memiliki karakter yang berbeda pula. Panjang tubuh lebah pekerja T. clypearis dari Negeri Hukurila, Negeri Rutong dan Dusun Seri lebih panjang dibandingkan dari Dusun Airlow, sedangkan panjang sayapnya dari Dusun Airlow lebih panjang dibandingkan dari Negeri Hukurila, Negeri Rutong dan Dusun Seri. 


\section{KESIMPULAN}

Kesimpulan-kesimpulan dari penelitian ini adalah sebagai berikut:

1. Spesies lebah tak bersengat yang ditemukan di daerah pesisir pantai tergolong dalam genus Tetragonula yang terdiri dari Tetragonula sapiens dan Tetragonula clypearis.

2. Tetragonula sapiens ditemukan di dua lokasi, yaitu di pesisir pantai Dusun Airlow dan Negeri Rutong.

3. Tetragonula clypearis ditemukan di empat lokasi, yaitu di pesisir pantai Dusun Airlow, Negeri Rutong, Negeri Hukurila dan Dusun Seri.

\section{DAFTAR PUSTAKA}

Bookhout, T.A. 1996. Research and management techniques for wildlife and habitats. Kansas (US): Allen Press Inc. ISBN-10: 093586881X.

Dollin A.E, L.J. Dollin, and S.F. Sakagami. 1997. Australian stingless bees of the genus Trigona (Hymenoptera: Apidae). Invertebrate Taxonomy. 11: 861-896. DOI: 10.1071/IT96020.

Kumar, M.S, A.J.A.R. Singh and G. Alagumuthu. 2012. Traditional beekeeping of stingless bees (Trigona sp.) by Kani tribes of Western Ghats, Tamil Nadu, India. Biology. Indian Journal of Traditional Knowledge. 11:342-345. http://nopr.niscair.res.in/ bitstream/123456789/54340/1/IJTK\%2019\%282\%29\%20428-434.pdf

Lamerkabel, J.S.A. 2011. Mengenal jenis-jenis lebah madu, produk-produk dan cara budidayanya. Logika, Jurnal Ilmu Pengetahuan dan Teknologi 9(1):70-78. . https://ejournal.unpatti.ac.id/ppr_paperinfo_lnk.php?id=841

Lamerkabel, J.S.A. 2017. Tabiat bersarang lebah madu tak bersengat Tetragonula biroi (F.) dan Tetragonula fuscobalteata (C.) asal Pulau Ambon, Maluku. Artikel Ilmiah. Presentasi Oral pada Seminar Nasional Perlebahan Indonesia. Kampus IPB Dramaga, Bogor.

Lamerkabel, J.S.A., H. Jesajas, and J.A. Leatemia. 2018. Distribution and nesting site of stingless bee (Tetragonula fuscobalteata Camaron) in Ambon Island, Maluku. Oral Presentation. Program Book. p.183. 14th Asian Apiculture Association (AAA) Conference 22-25 October 2018, Jakarta. http://repository.uinjkt.ac.id/dspace/bitstream/123456789/50763/1/The\%20 Effects\%20of\%20Temperature\%2C\%20Pests\%2C\%20Nectar-Producting\%20Plants\%20and\%20Log.pdf

Laurino, M.C, V.L.I. Fonseca, D.W. Roubik, A. Dollin, T. Heard, I.B. Aguilar, G.C. Venturieri, C. Eardley, and P.N. Neto. 2006. Global meliponiculture: Challenges and opportunities. Apidologie 37: 1-18. DOI: 10.1051/apido:2006027.

Leonhardt, S.D., K. Dworschak, T. Eltz, and N. Blüthgen. 2007. Foraging loads of stingless bees and utilisation of stored nectar for pollen harvesting. Apidologie 38, 125-135. DOI: 10.1051/apido:2006059.

Michener, C.D. 2007. The Bees of The World. Second Edition. The Johns Hopkins Univ. Press. Baltimore. ISBN-10: 0801885736, ISBN-13: 978-0801885730.

Rasmussen, C. 2008. Catalog of the Indo-Malayan/Australasian stingless bee (Hymenoptera: Apidae: Meliponini). Zootaxa. 1935:180. DOI: 10.11646/zootaxa.1935.1.1.

Rasmussen, C. and S.A. Cameron. 2010. Global stingless bee phylogeny supports ancient divergence, vicariance, and long-distance dispersal. Biological Journal of the Linnean Society 99:206-232. DOI: 10.1111/j.1095-8312.2009.01341.x.

Sakagami, S.F. 1978. Tetragonula stingless bee of the continental Asia and Sri Lanka (Hymenoptera, Apidae). Journal of the Faculty of Science, Hokkaido University, Series VI, Zoology 21: 165-247. https://eprints.lib.hokudai.ac.jp/dspace/bitstream/2115/ 27635/1/21\%282\%29_P165-247.pdf

Sakagami, S.F. and T. Inoue. 1987. Stingless bee of the genus Trigona (subgenus Trigonella) with notes on the reduction of spatha in male genitalia of the subgenus Tetragonula (Hymenoptera; Apidae). Kontyû 55(4): 610-627. https://dl.ndl.go.jp/view/ download/digidepo_10653539_po_ART0003853853.pdf?contentNo=1\&alternativeNo=

Sakagami, S.F., T. Inoue, and S. Salmah. 1990. Stingless bees of Central Sumatra. In: S.F. Sakagami, R.I Ohgushi, D.W. Roubik (Eds.), pp 125-137. Natural History of Social Wasps and Bees in Equatorial Sumatra. Hokkaido University Press, Sapporo, Japan.

Sihombing, D.T.H. 2005. Ilmu Ternak Lebah Madu. Gadjah Mada University Press, Yogyakarta. ISBN: 9794204080.

Smith, D. 2012. Indo-Malayan Stingless Bees: Key of Workers, p.1-42. The 1th Asian Apicultural Association (AAA) Conference Stingless Bee Workshop. September 28- October 2, 2012, Kuala Terengganu, Malaysia.

Suranto, A. 2004. Kiat dan Manfaat Madu Herbal. Agromedia Pustaka, Jakarta. ISBN: 979-3702-02-8. 